Article

\title{
No Tillage Improved Soil Pore Space Indices under Cover Crop and Crop Rotation
}

\author{
Dinesh Panday ${ }^{1, *(\mathbb{D})}$ and Nsalambi V. Nkongolo ${ }^{2,3}$ (D) \\ 1 Department of Biosystems Engineering and Soil Science, University of Tennessee, Knoxville, TN 37996, USA \\ 2 School of Science, Navajo Technical University, Crownpoint, NM 87313, USA; nnkongolo@navajotech.edu \\ 3 Institut Facultaire des Sciences Agronomiques (IFA) de Yangambi, \\ Kisangani BP 1232, Democratic Republic of the Congo \\ * Correspondence: dpanday@utk.edu or agriculturenepal@gmail.com
}

Citation: Panday, D.; Nkongolo, N.V. No Tillage Improved Soil Pore Space Indices under Cover Crop and Crop Rotation. Soil Syst. 2021, 5, 38. https://doi.org/10.3390/

soilsystems 5030038

Academic Editor: Heike Knicker

Received: 4 June 2021

Accepted: 2 July 2021

Published: 6 July 2021

Publisher's Note: MDPI stays neutral with regard to jurisdictional claims in published maps and institutional affiliations.

Copyright: (c) 2021 by the authors. Licensee MDPI, Basel, Switzerland This article is an open access article distributed under the terms and conditions of the Creative Commons Attribution (CC BY) license (https:/ / creativecommons.org/licenses/by/ $4.0 /)$.

\begin{abstract}
Assessment of the effects of crop management practices on soil physical properties is largely limited to soil moisture content, air content or bulk density, which can take considerable time to change. However, soil pore space indices evolve rapidly and could quickly detect changes in soil properties resulting from crop management practices, but they are not often measured. The objective of this study was to investigate how soil pore space indices-relative gas diffusion coefficient $\left(D_{s} / D_{o}\right)$ and pore tortuosity factor $(\tau)$ - are affected by tillage system (TL), cover crop (CC) and crop rotation (CR). A study was conducted on silt loam soil at Freeman farm, Lincoln University of Missouri during the 2011 to 2013 growing seasons. The experiment design was a randomized complete block with two tillage systems (no tillage or no-till vs conventional tillage), two cover crops (no rye vs cereal rye (Secale cereale L.)) and four crop rotations (continuous corn (Zea mays L.), continuous soybean (Glycine max L.), corn-soybean and soybean-corn successions). All the treatments were replicated three times for a total of 48 experimental units. Soils were collected from two sampling depths (SD), 0-10 and 10-20 cm, in each treatment and soil physical properties, including bulk density (BD), air-filled porosity (AFP, $\mathrm{f}_{\mathrm{a}}$ ) and total pore space (TPS, $\left.\Phi\right)$, were calculated. Gas diffusivity models following AFP and/or TPS were used to predict $D_{s} / D_{0}$ and $\tau$ values. Results showed that, overall, Ds/Do was significantly increased in no-tilled plots planted to cereal rye in $2012(p=0.001)$ and in 2013 ( $p=0.05)$. No-tilled continuous corn, followed by continuous soybean and no-tilled soybean-corn rotations had the highest Ds/Do values, respectively. In magnitude, Ds/Do was also increased in no-till plots at the lower depth $(10-20 \mathrm{~cm})$. No-tilled plots planted with cereal rye significantly reduced $\tau$ in $2012(p=0.001)$ and in $2013(p=0.05)$. Finally, at the upper depth $(0-10 \mathrm{~cm})$, the no-tilled corn-soybean rotation and the tilled soybean-corn rotation had the lowest $\tau$. However, at the lower depth $(10-20 \mathrm{~cm})$, the four crop rotations were not significantly different in their $\tau$ values. These results can be useful to quickly assess the changes in soil physical properties because of crop management practices and make necessary changes to enhance agricultural resilience.
\end{abstract}

Keywords: corn-soybean rotation; no tillage; pore tortuosity factor; relative gas diffusion coefficient; soil management

\section{Introduction}

A comprehensive understanding of the impact of crop management practices on soil properties is important in farm management to derive recommendations for optimal and sustainable utilization of land resources $[1,2]$. Nowadays, climate change-related threats and effects on agriculture are leading to increasingly urgent calls for farmers to adopt agricultural practices which can contribute to mitigating its impact and increase resilience and agricultural sustainability [3]. Some of the most common practices include the use of crop rotation, cover crops and no-tillage systems as essential elements of agroecosystem resilience [4]. The literature shows the varying magnitudes of the effects of conventional 
tillage on soil physical, chemical and biological properties [5-7]. When a tillage system in soil is changed from conventional to a no- or less-tillage system with crop residues that have been left behind on the surface, it may affect nearly all physical, chemical and biological properties $[8,9]$. However, there is much variability in the literature regarding soil bulk density (BD). Pikul et al. [10] carried out tillage research at eight different locations and found an increased, decreased or unchanged BD in surface soil.

Similarly, the inclusion of a cover crop in a cropping system is a source of organic matter from biomass produced, which enhances biological activities and subsequently improves soil quality [11-13]. However, the literature also contains the evidence of no changes in soil structural properties due to addition of cover crops [14]. The use of cover crops increases the diversity and intensity of crop rotations $[15,16]$. Besides inclusion of cover crops, crop rotation also can include slow-decomposition plants with a high potential for dry matter production, e.g., corn, as well as legumes with high potential for biological nitrogen fixation and with faster decomposition, e.g., soybean, providing numerous benefits for any cropping system [17]. For example, crop rotation reduces the incidence of pests and diseases, improves nutrient use and reduces weed pressure [18,19]. Some other crop rotation studies suggested that the improvement of soil structural porosity to enhance hydraulic behavior [20] and water retention [21] was due to the presence of crop species. Hence, designing an appropriate crop rotation is a mix of art and science to maximize its benefit along with the tillage system and/or inclusion of cover crops. However, there are very few studies which have reported a combination of tillage system, crop rotation and cover crop effects on soil properties.

The soil pore system is a primary structural component controlling the air and water exchange in soil [22], and which is dominated by pore size abundance, tortuosity and continuity [23]. These pores influence soil biodiversity by providing a habitat for microorganisms and govern many soil processes [13]. Soil aeration and compaction are common problems that farmers face frequently which indirectly affect soil productivity and environmental quality. While the pore space is critical to any changes in soil and crop management practices, it has always received little attention and assessing the effects of soil and crop management practices is largely limited to soil properties such as moisture content or bulk density $[24,25]$.

Gas movement in soil is a phenomenon that occurs mainly by diffusion. Large pores allow more rapid movement of gases compared to small pores. For instance, greenhouse gases produced in soil travel through the pore space before being emitted to the atmosphere [26]. Gas diffusivity for a given gas in soil (Ds) is a commonly expressed relative to the diffusivity of this same gas in free air (Do) and is commonly known as relative diffusion coefficient (Ds/Do). A quantity that characterizes the convoluted nature of the porous pathways followed by diffusing species is known as pore tortuosity factor $(\tau)$ [27]. The actual path length through a porous material can be calculated from measurements of other parameters only and having a lower value of $\tau$ indicates a shorter pathway in a pore space [28]. Soil pore space indices include both gas diffusion and tortuosity properties of pore spaces [29]. Agricultural practices can bring about changes in these variables and cause great fluctuation in the retention and movement of water and gas exchange between soil and atmosphere [30,31]. Quantification of pore space indices can provide clear information about retention and movement of air and water in soil [32].

The direct measurement of Ds/Do and $\tau$ in the field are tedious, expensive and time consuming [33]. There are many predictive models/equations which describe soil diffusivity processes for undisturbed soils in the vadose zone. As an example, some models are based on air-filled porosity (AFP) alone and are linear, some are a combination of AFP and total porosity (TPS) and are nonlinear, while others use saturated hydraulic conductivity, soil water curve, etc. [26,34]. However, there is still no clear information that which model(s) can predict indices better to soil processes following different crop management practices. Hence, the objective of the current study was to explore the effectiveness of a combination of tillage system, cover crop and crop rotation on selected 
soil physical properties, i.e., bulk density and pore space indices_-Ds /Do and $\tau$-in a silt loam soil.

\section{Materials and Methods}

\subsection{Experimental Field and Treatment}

A research experiment was conducted at the Freeman farm, Callaway County of the Lincoln University of Missouri, United States. The experimental site coordinates are $38^{\circ} 34^{\prime} 55.8^{\prime \prime} \mathrm{N}, 92^{\circ} 06^{\prime} 26.9^{\prime \prime} \mathrm{W}$. The soil of experimental site is Waldron silt loam which belongs to the soil order Entisol (Aeric Fluvaquents), 1-2\% slopes, $6.7 \mathrm{pH}$ and around 1.7\% organic matter. During three years of study (2011-2013), the mean annual temperature and precipitation was $13{ }^{\circ} \mathrm{C}$, with January as coldest and July as warmest months and $990.6 \mathrm{~mm}$, respectively [35]. The year of 2012 was a comparatively dry year with an annual mean precipitation of $752.1 \mathrm{~mm}$. Crops used in the study were corn, soybean and cereal rye. The choice of cereal rye cover crop in this research was according to the Sustainable Corn Project protocol as it is the most widely adapted cover crop across the 8-state project in the United States.

An experimental design was set up in a three-factor factorial design and arranged in a randomized complete block with three replications. The three factors/treatments were (i) tillage at two levels: no tillage vs conventional tillage (using a moldboard plow at a depth of 10-20 cm), (ii) cover crop at two levels (cereal rye vs no rye) and (iii) cropping rotation or sequence at four levels (continuous corn, continuous soybean, corn-soybean and soybean-corn rotations). There were 48 experimental plots (Figure 1) and each plot was $12.2 \mathrm{~m}$ in width and $21.3 \mathrm{~m}$ in length.
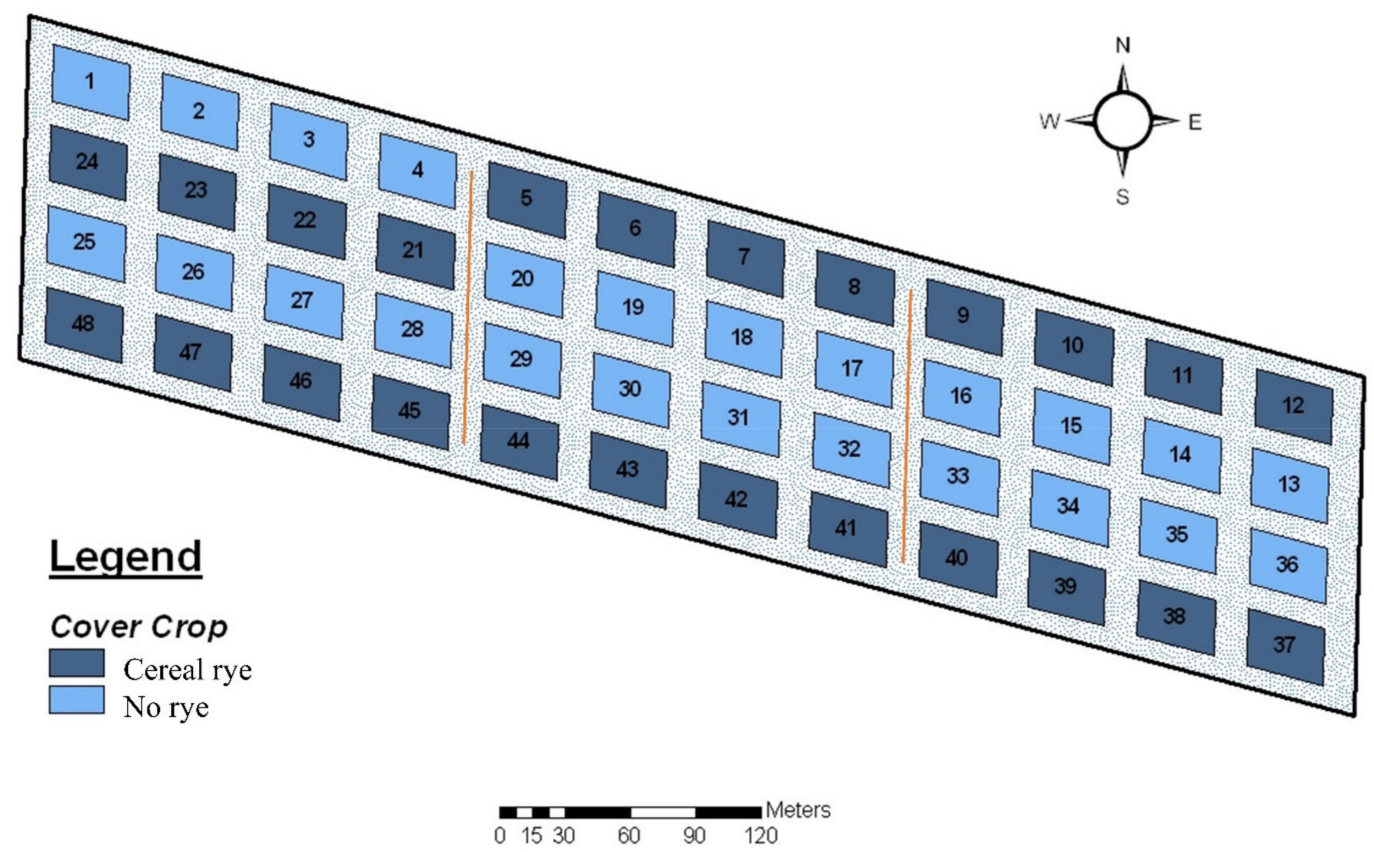

Figure 1. Experimental field at Freeman farm, Lincoln University of Missouri. Treatment-wise, there were three factors (tillage system, cover crop and crop rotation). However, the figure shows only cover crop at two levels.

Every year, 24 plots were used for growing corn (12 continuous corn and 12 cornsoybean rotations) and the remaining 24 plots for soybean (12 continuous soybean and 12 soybean-corn rotations). Following it, 24 plots were used for cereal rye and another 24 plots for the no-rye cover crop. Fields were prepared in the spring season, corn was planted in May and soybeans in June, both crops were harvested in October. Cereal rye was planted in October after the harvest of corn and soybean and was terminated in early May each year. No tillage, no rye, continuous corn and continuous soybean were considered as 
control treatments. Fertilizers were applied at a rate of 26.3:67.3:89.7 $\mathrm{kg} \mathrm{NPK} \mathrm{ha}^{-1}$ in all corn and soybean plots every year as a basal dose before planting. Additional $\mathrm{N}$ in from urea incorporation, as an injection into the no-tillage plots, was applied in corn plots at the rate of $201.8 \mathrm{~kg} \mathrm{~N} \mathrm{ha}^{-1}$.

\subsection{Soil Sampling and Measurements}

Soil sampling protocol for the current study was reported by Kladivko et al. [36]. Every year after planting and the full emergence of the crop seeds, soil samples were collected from two depths: surface or $0-10 \mathrm{~cm}$ and sub-surface or 10-20 cm, at 3 random locations (representing samples from furrow and ridge sections in between two rows of corn or soybean around the center of each plot with no trafficking) in the field with the help of a cylindrical core sampler (volume of core was $311.57 \mathrm{~cm}^{3}$ ). Soil fresh weights were measured and then soil samples were dried at $105^{\circ} \mathrm{C}$ for $72 \mathrm{~h}$ in oven. Later, soil BD (in $\mathrm{g} \mathrm{cm}^{-3}$ ), AFP (in \%) and TPS (in $\mathrm{cm}^{3} \mathrm{~cm}^{-3}$ ) were calculated.

The Ds/Do (in $\mathrm{m}^{2} \mathrm{~s}^{-1} \mathrm{~m}^{-2} \mathrm{~s}$ or dimensionless) and the $\tau$ (in $\mathrm{m}^{1} \mathrm{~m}^{-1}$ or dimensionless) were predicted by the following five equations based on AFP $\left(f_{a}\right)$ (see Marshall [37] and Buckingham [38]) or a combination of AFP and TPS ( $\Phi)$ (see Sallam et al. [39], Millington [40] and Jin and Jury [41]) which are described by Nkongolo et al. [29] as below: Ds/Do either as a function of air-filled porosity alone:

Ds $/$ Do $=\mathrm{f}_{\mathrm{a}}{ }^{1.5}$ (Marshall [37])

Ds $/$ Do $=\mathrm{f}_{\mathrm{a}}{ }^{2}$ (Buckingham [38])

or as a quotient of air-filled porosity over total porosity $(\Phi)$ :

Ds $/$ Do $=\mathrm{f}_{\mathrm{a}} 3.1 / \Phi_{2}$ (Sallam et al. [39])

Ds $/$ Do $=\mathrm{f}_{\mathrm{a}}{ }^{3.33} / \Phi_{2}$ (Millington [40])

Ds $/$ Do $=\mathrm{f}_{\mathrm{a}}{ }^{2} / \Phi_{2 / 3}$ (Jin and Jury [41])

$\tau$ either as a function of air-filled porosity alone:

$\tau=1 / \mathrm{f}_{\mathrm{a}}{ }^{0.5}$ (Marshall [37])

$\tau=1 / \mathrm{f}_{\mathrm{a}}$ (Buckingham [38])

or as a quotient of total porosity $(\Phi)$ over air-filled porosity:

$\tau=\Phi_{2} / \mathrm{f}_{\mathrm{a}}{ }^{2.1}$ (Sallam et al. [39])

$\tau=\Phi_{2} / \mathrm{f}_{\mathrm{a}}{ }^{2.33}$ (Millington [40])

$\tau=\Phi_{2 / 3} / f_{a}($ Jin and Jury [41])

\subsection{Statistical Analysis}

The effects of treatment (tillage system, cover crop, crop rotation, including sampling depth) on measured variables were tested by analysis of variance (ANOVA) in Statistix 10.0 software. Means were compared using the least significant difference (LSD) multiple range tests. Statistical significance was evaluated at $p<0.05$. All graphs were produced in SigmaPlot 13.0 software.

\section{Results and Discussion}

\subsection{Effect of Tillage System, Cover Crop and Crop Rotation on Bulk Density}

The effects of tillage system (TL), cover crop (CC) and crop rotation (CR), including sampling depth (SD) on BD from the study period is shown in Table 1. In 2011, which was also the first year of study, only TL and SD were considered for BD measurement. This was because the effect of $C C$ and $C R$ treatments would be more reasonable to observe the changes in soil physical properties in subsequent years. In 2011, there was a significant effect of SD on BD (Table 1). The BD was higher (by 7.1\%) at $10-20 \mathrm{~cm}$ than at $0-10 \mathrm{~cm}$ depths. As seen in the literature, BD increases with the increase in soil depth because subsurface layers have reduced organic matter, soil aggregation, and root penetration compared to surface layers, resulting in less pore space availability [42-44]. In contrast, the expansion of crop roots, as well as the accumulation of plant residues on soil surface 
layers, can improve productivity of soil by enhancing aggregate stability, pore space and organic matter and reduces the BD [45,46]. Biopores produced from the dead root are important not only for lowering BD but also for improving gas exchange and water infiltration [47]. Broadly, depth increments of soil sampling also affect BD differences [31], and large depth increment samples might obscure those differences compared to small depth increments [48].

Table 1. Analysis of variance (ANOVA) results with means for bulk density as affected by tillage system, cover crop, crop rotation and sampling depth and their interactions.

\begin{tabular}{|c|c|c|c|}
\hline \multirow{2}{*}{ Source of Variation } & \multicolumn{3}{|c|}{ Bulk Density, $\mathrm{Mg} \mathrm{m}^{-3}$} \\
\hline & 2011 & 2012 & 2013 \\
\hline \multicolumn{4}{|l|}{ Treatment } \\
\hline \multicolumn{4}{|l|}{ Tillage system (TL) } \\
\hline No tillage & 1.3 & 1.4 & 1.3 \\
\hline Conventional tillage & 1.3 & 1.4 & 1.3 \\
\hline Significance & NS & NS & NS \\
\hline \multicolumn{4}{|l|}{ Cover crop (CC) } \\
\hline No rye & - & 1.5 & 1.3 \\
\hline Cereal rye & - & 1.3 & 1.3 \\
\hline Significance & & $*$ & NS \\
\hline \multicolumn{4}{|l|}{ Crop rotation (CR) } \\
\hline Continuous Corn & - & 1.4 & 1.3 \\
\hline Continuous Soybean & - & 1.4 & 1.3 \\
\hline Corn-Soybean & - & 1.5 & 1.3 \\
\hline Soybean-Corn & - & 1.4 & 1.3 \\
\hline Significance & & NS & NS \\
\hline \multicolumn{4}{|l|}{ Sampling depth (SD) } \\
\hline $0-10 \mathrm{~cm}$ & $1.3 \mathrm{~b}^{+}$ & 1.4 & 1.3 \\
\hline $10-20 \mathrm{~cm}$ & $1.4 \mathrm{a}$ & 1.5 & 1.3 \\
\hline Significance & $*$ & $*$ & NS \\
\hline \multicolumn{4}{|l|}{ Interactions } \\
\hline $\mathrm{TL} \times \mathrm{SD}$ & NS & NS & NS \\
\hline $\mathrm{CC} \times \mathrm{SD}$ & - & * & NS \\
\hline $\mathrm{CR} \times \mathrm{SD}$ & - & NS & NS \\
\hline $\mathrm{TL} \times \mathrm{CC}$ & - & NS & * \\
\hline $\mathrm{TL} \times \mathrm{CR}$ & - & NS & NS \\
\hline $\mathrm{CC} \times \mathrm{CR}$ & - & NS & * \\
\hline $\mathrm{TL} \times \mathrm{CC} \times \mathrm{SD}$ & - & NS & NS \\
\hline $\mathrm{TL} \times \mathrm{CR} \times \mathrm{SD}$ & - & NS & NS \\
\hline $\mathrm{CC} \times \mathrm{CR} \times \mathrm{SD}$ & - & NS & NS \\
\hline $\mathrm{TL} \times \mathrm{CC} \times \mathrm{CR} \times \mathrm{SD}$ & - & NS & NS \\
\hline
\end{tabular}

$\mp$ Means in a column followed by same lowercase letter are not significantly different. ${ }^{*} p<0.05$ and NS = not significant.

A significant interaction effect of CC $\times$ DS on BD was observed in 2012 (Table 1). Cover crop with cereal rye at $0-10$ and $10-20 \mathrm{~cm}$ soil depths had the lowest and highest value of BD, respectively (Figure 2a). Though we did not measure soil compaction after the treatment was applied, it favors root activity, nutrient uptake and air, water and heat flow through soil profile when there is inclusion of cereal rye as cover crop than no cover crop [49]. Wagger and Denton [50] reported that when cover crops are actively growing, it depletes more soil moisture just before subsoiling and planting operations, increases the AFP (by reducing soil compaction) and ultimately reduce the BD of soil [51,52]. 


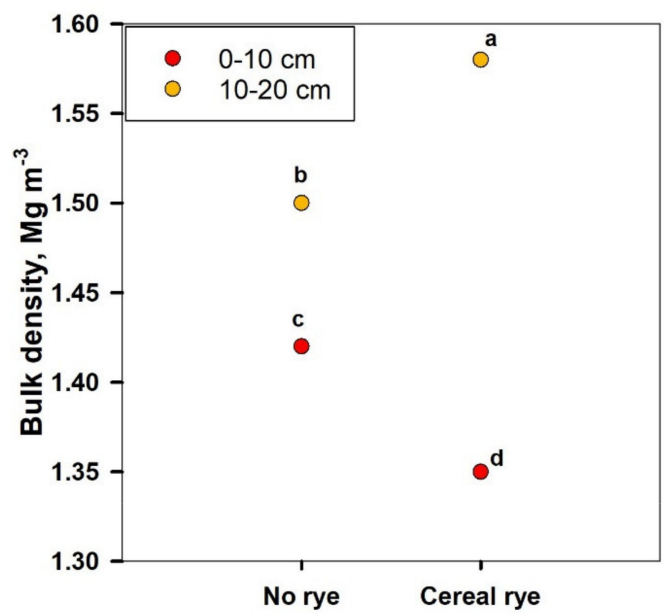

a) Cover crop $x$ Sampling depth interaction

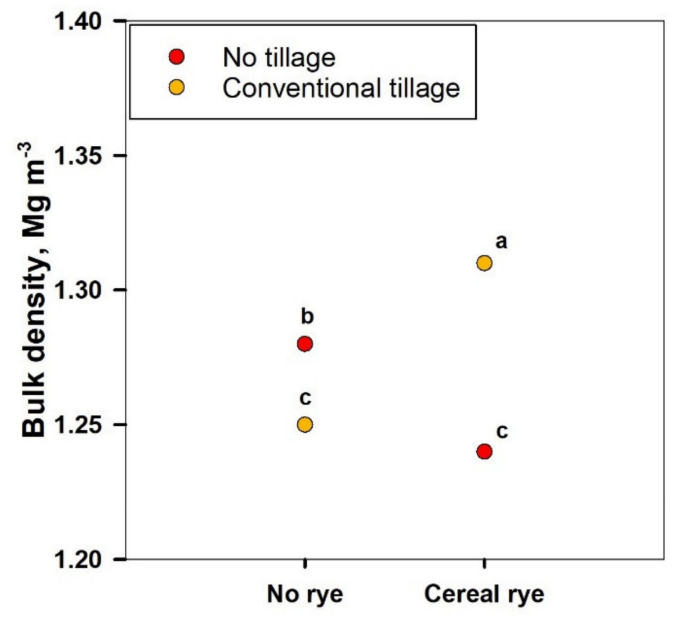

b) Cover crop $\mathrm{x}$ Tillage system interaction

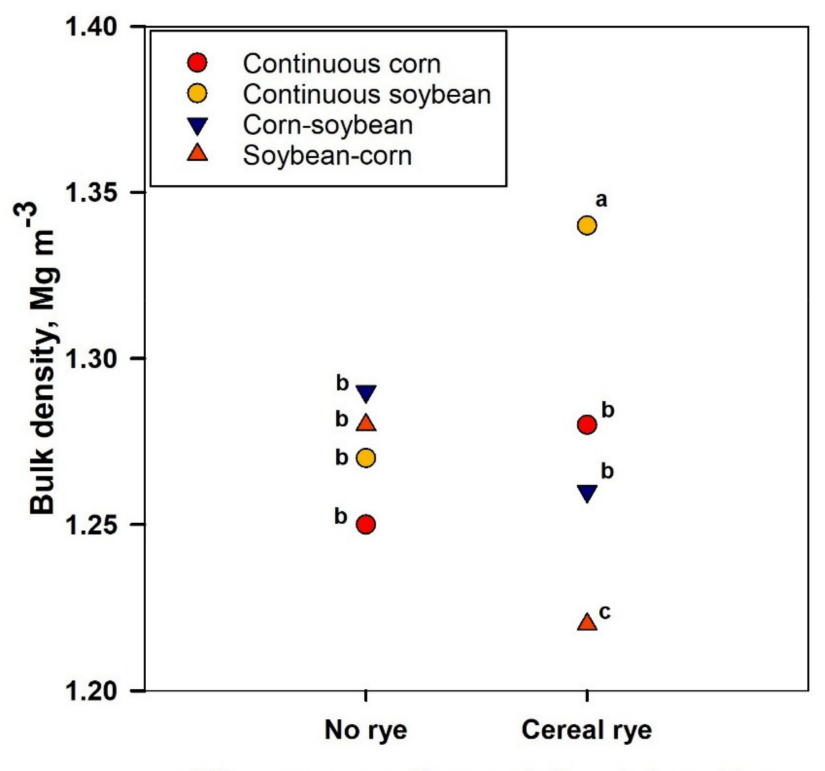

c) Cover crop x Crop rotation interaction

Figure 2. Interaction effect of different treatments on means of bulk density: (a) cover crop $\times$ sampling depth in 2012 , (b) cover crop $\times$ tillage system and (c) cover crop $\times$ crop rotation in 2013. Means followed by the same lowercase letter are not significantly different.

Similarly, there were significant interaction effects of TL $\times$ CC and CC $\times$ CR on BD in 2013 (Table 1). Cereal rye with conventional tillage had a higher BD compared to cereal rye and no-tillage or no-rye and no-tillage (Figure $2 \mathrm{~b}$ ). Inclusion of cereal rye in continuous soybean and soybean-corn rotations had the highest and lowest BD, respectively (Figure 2c). Bulk density under cereal rye varied by continuous soybean rotation and conventional tillage. Conventional tillage favors the breakdown of macro-aggregates in the soil system [53]. However, the inclusion of cover crops for breaking up macro-aggregates and compact layers instead of implementing mechanical or conventional tillage has been strongly articulated in many findings $[47,54,55]$. Results conclude that the addition of cereal rye as a cover crop under a no-tillage system in a soybean-corn rotation remained an effective mechanism for reducing BD in cropping land. Nevertheless, our field studies showed uncertainties around the continuation of interaction effects present in 2013 from 2012. It is difficult to predict the soil's physical properties adequately and accurately, including BD, due to the complex nature of soil and crop management practices $[51,56]$. 
By following five diffusivity equations to estimate changes on soil pore space indices due to TL, CC and CR practices over time, we found that Marshall and Millington equations predicted the strongest Ds/Do and $\tau$, respectively. These equations also had the lowest coefficient of variation compared to other equations (data not shown). Henceforth, Ds/Do and $\tau$ values are presented based on Marshall and Millington equations, respectively. More information about the comparison of equations using diffusivity models and calculations can be found in Panday and Nkongolo [26].

\subsection{Effects of Tillage System, Cover Crop and Crop Rotation on Relative Gas Diffusion Coefficient}

There was a significant effect of SD, as well as a significant interaction effect of TC $\times$ CR on the relative gas diffusion coefficient (Ds/Do) in 2011 (Table 2). The Ds/Do was higher at $0-10 \mathrm{~cm}$ than at 10-20 cm depths. Similarly, Ds/Do was the highest and lowest in continuous corn and soybean-corn rotations under a no-tillage system, whereas no significant difference was observed in CR under conventional tillage. The Ds/Do ranged from $0.07-0.13 \mathrm{~m}^{2} \mathrm{~s}^{-1} \mathrm{~m}^{-2} \mathrm{~s}$ (Figure 3a). All evaluated three- or four-way interaction effects of treatment(s) on Ds/Do were insignificant. Surface soil, in the presence or absence of tillage, increases evaporation of soil moisture compared to the sub-surface and increases the AFP [51]. Since conventional tillage breaks many macropores and cracks compared to undisturbed no-tillage soils [57], except for the soybean-corn rotation, all other combinations had a higher or equal Ds/Do in soil.

Table 2. ANOVA results with means for relative gas diffusion coefficient as affected by tillage system, cover crop, crop rotation and sampling depth and their interactions.

\begin{tabular}{|c|c|c|c|}
\hline \multirow{2}{*}{ Source of Variation } & \multicolumn{3}{|c|}{ Relative Gas Diffusion Coefficient, $\mathrm{m}^{2} \mathrm{~s}^{-1} \mathrm{~m}^{-2} \mathrm{~s}$} \\
\hline & 2011 & 2012 & 2013 \\
\hline \multicolumn{4}{|l|}{ Treatment } \\
\hline \multicolumn{4}{|l|}{ Tillage (TL) } \\
\hline No tillage & 0.11 & $0.11 \mathrm{a}^{+}$ & $0.10 \mathrm{a}$ \\
\hline Conventional tillage & 0.10 & $0.07 \mathrm{~b}$ & $0.08 \mathrm{~b}$ \\
\hline Significance & NS & $* * *$ & $*$ \\
\hline \multicolumn{4}{|l|}{ Cover crop (CC) } \\
\hline No rye & 0.11 & 0.10 & 0.09 \\
\hline Cereal rye & 0.10 & 0.08 & 0.08 \\
\hline Significance & NS & NS & NS \\
\hline \multicolumn{4}{|l|}{ Crop rotation $(\mathrm{CR})$} \\
\hline Continuous Corn & 0.11 & 0.08 & 0.10 \\
\hline Continuous Soybean & 0.10 & 0.11 & 0.09 \\
\hline Corn-Soybean & 0.11 & 0.08 & 0.08 \\
\hline Soybean-Corn & 0.09 & 0.08 & 0.09 \\
\hline Significance & NS & NS & NS \\
\hline \multicolumn{4}{|l|}{ Sampling depth (SD) } \\
\hline $0-10 \mathrm{~cm}$ & $0.13 a$ & $0.10 \mathrm{a}$ & $0.10 \mathrm{a}$ \\
\hline $10-20 \mathrm{~cm}$ & $0.08 \mathrm{~b}$ & $0.08 \mathrm{~b}$ & $0.08 \mathrm{~b}$ \\
\hline Significance & $* * *$ & * & $* *$ \\
\hline \multicolumn{4}{|l|}{ Interactions } \\
\hline $\mathrm{TL} \times \mathrm{SD}$ & NS & NS & NS \\
\hline $\mathrm{CC} \times \mathrm{SD}$ & NS & NS & NS \\
\hline $\mathrm{CR} \times \mathrm{SD}$ & NS & NS & NS \\
\hline $\mathrm{TL} \times \mathrm{CC}$ & NS & * & $* *$ \\
\hline $\mathrm{TL} \times \mathrm{CR}$ & $* *$ & NS & NS \\
\hline $\mathrm{CC} \times \mathrm{CR}$ & NS & NS & NS \\
\hline
\end{tabular}


Table 2. Cont.

\begin{tabular}{cccc}
\hline \multirow{2}{*}{ Source of Variation } & \multicolumn{3}{c}{ Relative Gas Diffusion Coefficient, $\mathbf{~ m}^{\mathbf{2}} \mathbf{s}^{-\mathbf{1}} \mathbf{m}^{-\mathbf{2}} \mathbf{s}$} \\
\cline { 2 - 4 } & $\mathbf{2 0 1 1}$ & $\mathbf{2 0 1 2}$ & $\mathbf{2 0 1 3}$ \\
\hline $\mathrm{TL} \times \mathrm{CC} \times \mathrm{SD}$ & $\mathrm{NS}$ & $* *$ & $* * *$ \\
$\mathrm{TL} \times \mathrm{CR} \times \mathrm{SD}$ & $\mathrm{NS}$ & $\mathrm{NS}$ & $\mathrm{NS}$ \\
$\mathrm{CC} \times \mathrm{CR} \times \mathrm{SD}$ & $\mathrm{NS}$ & $\mathrm{NS}$ & $\mathrm{NS}$ \\
$\mathrm{TL} \times \mathrm{CC} \times \mathrm{CR} \times \mathrm{SD}$ & $\mathrm{NS}$ & $\mathrm{NS}$ \\
\hline T & Means in column followed by
\end{tabular}

† Means in a column followed by same lowercase letter are not significantly different. ${ }^{*} p<0.05,{ }^{* *} p<0.01$, $* * * p<0.001$ and NS = not significant.

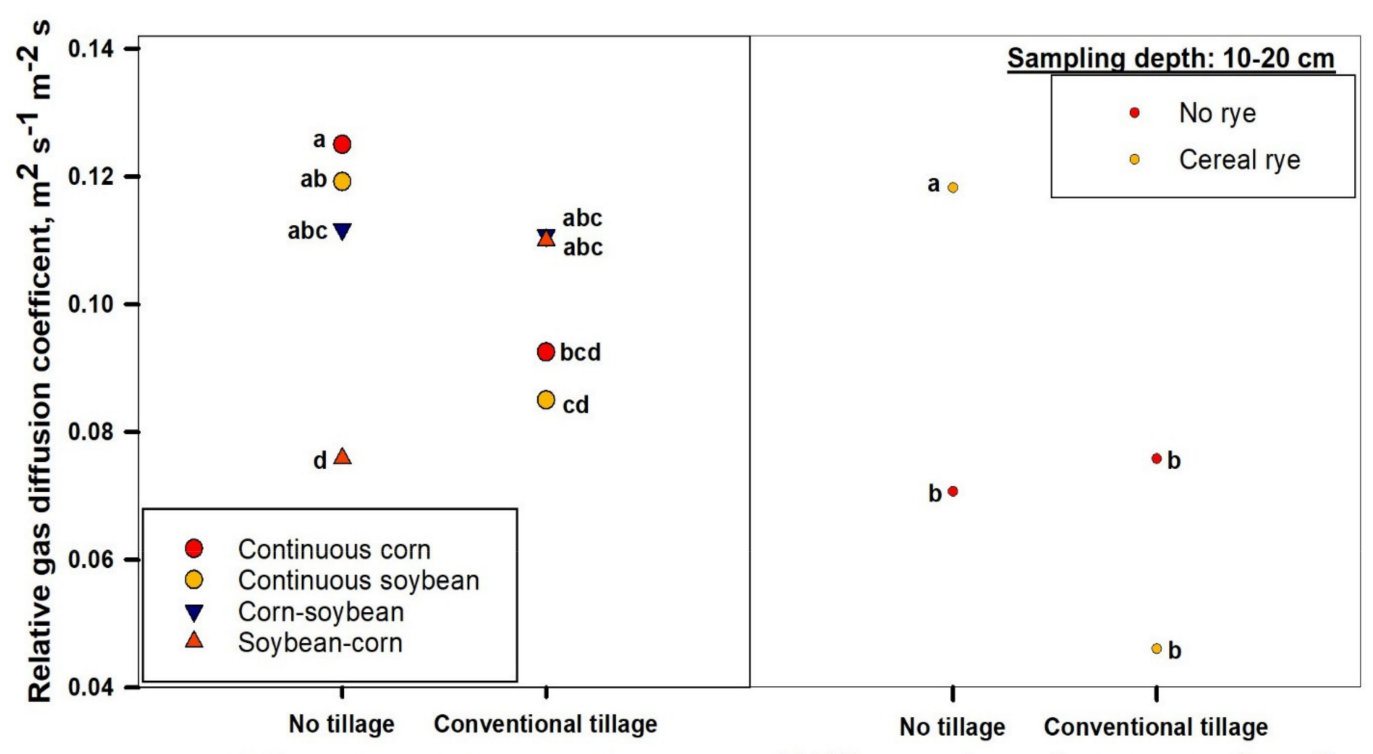

a) Tillage sytem $x$ Crop rotation

b) Tillage system $x$ Cover crop $x$ Sampling interaction depth interaction

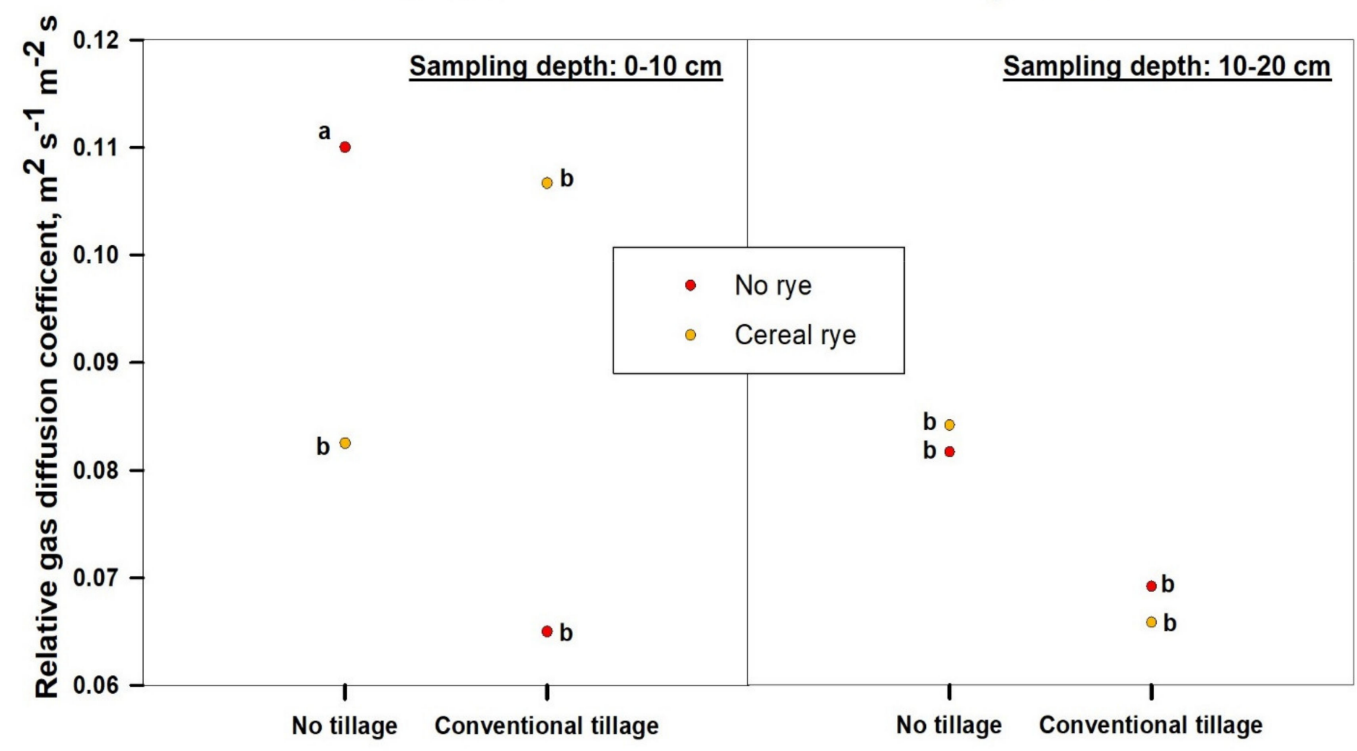

c) Tillage system $x$ Cover crop $x$ Sampling depth interaction

Figure 3. Interaction effect of different treatments on means of relative gas diffusion coefficient: (a) tillage system $\times$ crop rotation in 2011, (b) tillage system $\times$ cover crop $\times$ sampling depth at 10-20 cm in 2012 (note: tillage system $\times$ cover crop $\times$ sampling depth at $0-10 \mathrm{~cm}$ in 2012 was not significant at $p<0.05)$ and (c) tillage system $\times$ cover crop $\times$ sampling depth in 2013. Means followed by the same lowercase letter are not significantly different. 
The Ds / Do was significantly affected by interactions of TL $\times$ CC $\times$ SD in 2012 (Table 2 and Figure 3b). For Ds /Do, TL $\times$ CC interaction effect was significant only at $10-20 \mathrm{~cm}$, but not at $0-10 \mathrm{~cm}(p=0.71)$. The study year 2012 was comparatively drier than other years. Although not significant in Ds/Do, residues of cereal rye, as well as corn from the previous year, could help in the reduction of evapotranspiration from surface soil, indicating a potential increase in bio-pores [51,58]. Similar results were reported by Nielson et al. [59] and Basche et al. [60] that cover crops can reduce water availability for the next crops in water-limiting conditions. Figure $3 b$ shows that the inclusion of a cereal rye and no tillage increased Ds/Do at 10-20 cm depth compared to other treatment combinations. However, cereal rye under conventional tillage was not significant on Ds/Do, which could be due to the heterogeneity of soil at 10-20 cm depth [61]. For example, conventional tillage as well as wet soil conditions increases the soil compactness and hence decrease Ds/Do [62].

Similarly, the Ds/Do was significantly affected by interactions of TL $\times \mathrm{CC} \times \mathrm{SD}$ in 2013 (Table 2 and Figure 3c). No tillage with no inclusion of cereal rye increased Ds/Do regardless of SD and there were no significant differences in Ds/Do among other treatment combinations (Figure 3c). Except for 2011, all other years had three-way TL $\times$ CC $\times$ SD interaction effects on Ds/Do, which is strong evidence to evaluate soil aeration, diffusion and biodegradation of greenhouse gases emissions [26,51,63]. At the same time, soil and crop management practices and their complex interactions warrant a long-term study to predict their effects on Ds/Do.

\subsection{Effects of Tillage System, Cover Crop and Crop Rotation on Pore Tortuosity Factor}

There was a significant main effect of SD, as well as an interaction effect of TL $\times$ CR on pore tortuosity factor $(\tau)$ in 2011 (Table 3). However, the $\tau$ was higher at $10-20 \mathrm{~cm}$ than at $0-10 \mathrm{~cm}$ depths. Possibly because it was the first year of the study, a minimal significant difference was observed in soybean-corn rotation or continuous corn under a no-tillage system, as well as continuous corn or continuous soybean under a conventional tillage system. The $\tau$ ranged from $8.11-13.68 \mathrm{~m} \mathrm{~m}^{-1}$ (Figure $4 \mathrm{~b}$ ), although it is not clear that there is a higher $\tau$ value in sub-surface than surface soil, which could be due to relatively higher soil compaction and lower macro-porosity at a 10-20 cm depth [64]. The BD results from 2011 (Table 2) showed a direct relationship to these results, which aligns with the study of Chou et al. [65].

There was a significant interaction effect of TL $\times$ CC on $\tau$ in 2012 (Table 3 and Figure 4a). Results suggest that treatment combinations of no rye, with or without having tillage, increased $\tau$ compared to cereal rye under no tilled plots. This suggests a change in aeration due to microbial movement in undisturbed soils $[49,66]$ and cereal rye roots may have contributed to improvement of soil porosity [51,67]. All evaluated three- or four-way interaction effects of treatment(s) on $\tau$ were insignificant in 2011 and 2012.

Similarly, there was a significant interaction effect of TL $\times C R \times S D$ on $\tau$ in 2013 (Table 3 and Figure 4c). The differences found amongst the different CR and TL practices on the surface had disappeared in the sub-surface soils (Figure 4c). Pore tortuosity factor in 2013 was almost two times higher compared to its value in 2012 and three times higher from 2011 at 0-10 cm depth (Table 3). However, no such difference was observed at 10-20 cm depth. Tillage operations can destroy pore continuity; the higher the $\tau$, the lower the gas and water fluxes and there can be a possible detrimental impact on soil functionality $[13,68]$. On the other hand, the lack of difference between no-till and conventional tillage in $\tau$ at $0-10 \mathrm{~cm}$ depth in 2013 may be due to the biosphere remaining functional after crop harvest, which coincided with the soil sampling time [67]. In the present study, corn-soybean rotation under conventional tillage and soybean-corn rotation under no tillage had a higher $\tau$ at 0-10 cm depth. One of the pitfalls studies presented Ds/Do and $\tau$ in a calculation based on different equations. Girei et al. [33] predicted both the highest Ds/Do and lowest $\tau$ based only on AFP, suggesting that the complexity involved in both AFP and TPS in the AFP + TPS (i.e., $\left.f_{a}+\Phi\right)$ may result in the poor performance of the model. It is possible that, 
if a similar diffusivity model were used, the result would have been similar in respect to applied treatments and their interactions [69].

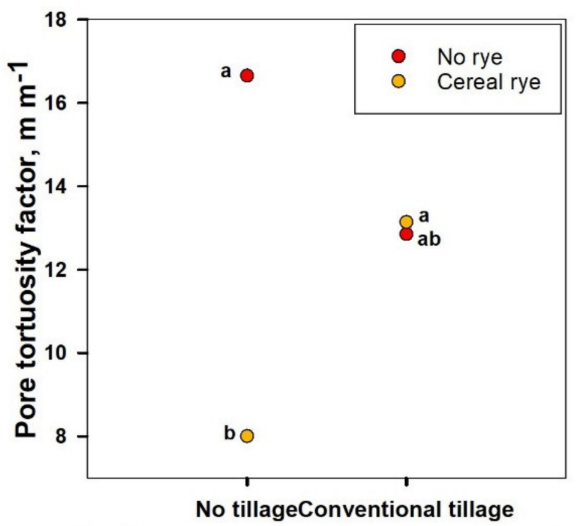

a) Tillage system $x$ Cover crop interaction

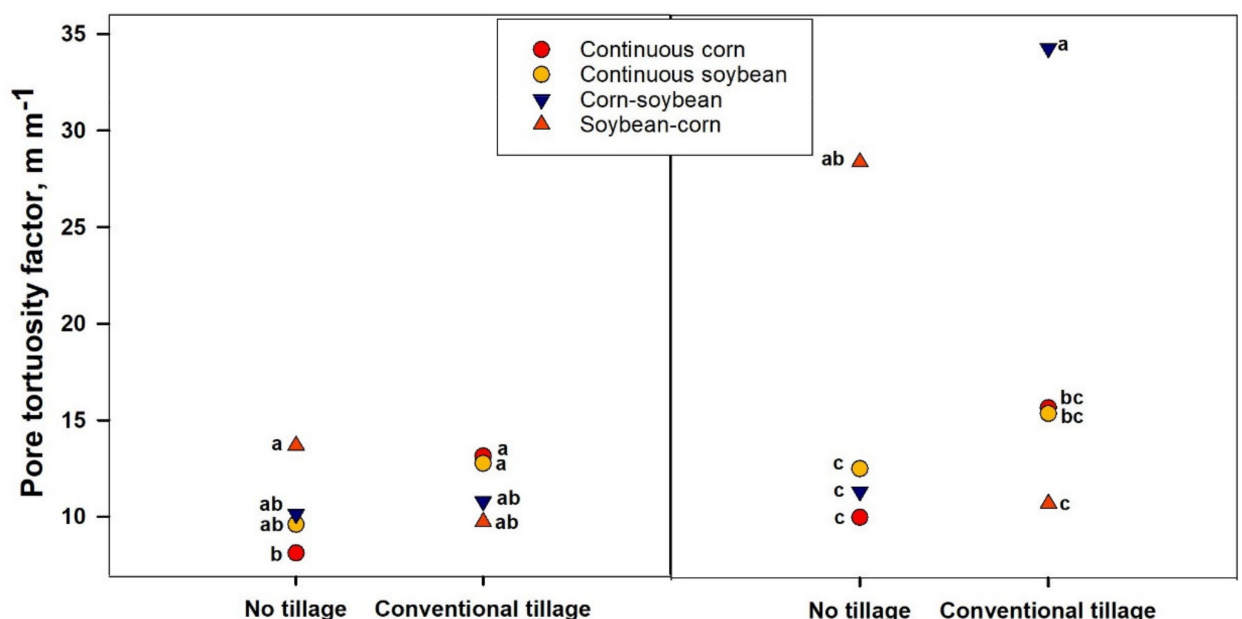

b) Tillage system $\times$ Crop rotation interaction (Left in 2011 and right in 2013)

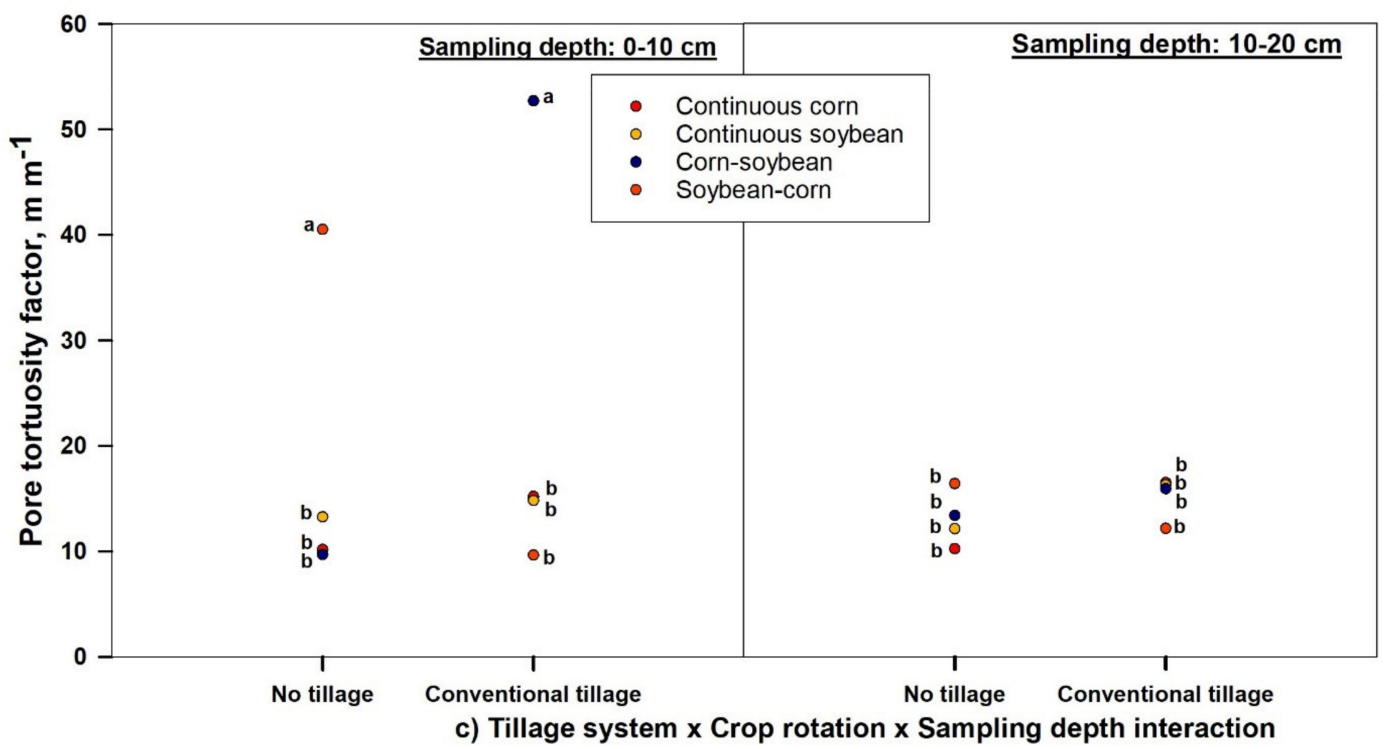

Figure 4. Interaction effect of different treatments on means of pore tortuosity factor: (a) tillage system $\times$ cover crop in 2012 , (b) tillage system $X$ crop rotation in 2011 (left) and 2013 (right) and (c) tillage system $\times$ crop rotation $\times$ sampling depth in 2013. Means followed by same lowercase letter are not significantly different. 
Table 3. ANOVA results with means for pore tortuosity factor as affected by tillage system, cover crop, crop rotation and sampling depth and their interactions.

\begin{tabular}{|c|c|c|c|}
\hline \multirow{2}{*}{ Source of Variation } & \multicolumn{3}{|c|}{ Pore Tortuosity Factor, $\mathrm{m} \mathrm{m}^{-1}$} \\
\hline & 2011 & 2012 & 2013 \\
\hline \multicolumn{4}{|l|}{ Treatment } \\
\hline \multicolumn{4}{|l|}{ Tillage system (TL) } \\
\hline No tillage & 10.38 & 12.33 & 15.71 \\
\hline Conventional tillage & 11.60 & 13.00 & 19.14 \\
\hline Significance & NS & $* * *$ & * \\
\hline \multicolumn{4}{|l|}{ Cover crop (CC) } \\
\hline No rye & 10.65 & 12.33 & 19.05 \\
\hline Cereal rye & 11.34 & 13.00 & 15.80 \\
\hline Significance & NS & NS & NS \\
\hline \multicolumn{4}{|l|}{ Crop rotation (CR) } \\
\hline Continuous Corn & 10.62 & $12.36 \mathrm{ab}^{+}$ & 13.01 \\
\hline Continuous Soybean & 11.18 & $10.50 \mathrm{~b}$ & 14.11 \\
\hline Corn-Soybean & 10.47 & $12.19 \mathrm{ab}$ & 22.91 \\
\hline Soybean-Corn & 11.70 & $15.60 \mathrm{a}$ & 19.67 \\
\hline Significance & NS & NS & NS \\
\hline \multicolumn{4}{|l|}{ Sampling depth (SD) } \\
\hline $0-10 \mathrm{~cm}$ & $7.88 b$ & 11.45 & 20.74 \\
\hline $10-20 \mathrm{~cm}$ & $14.11 \mathrm{a}$ & 13.87 & 14.11 \\
\hline Significance & $* * *$ & NS & NS \\
\hline \multicolumn{4}{|l|}{ Interactions } \\
\hline $\mathrm{TL} \times \mathrm{SD}$ & NS & NS & NS \\
\hline $\mathrm{CC} \times \mathrm{SD}$ & NS & NS & NS \\
\hline $\mathrm{CR} \times \mathrm{SD}$ & NS & NS & NS \\
\hline $\mathrm{TL} \times \mathrm{CC}$ & NS & * & NS \\
\hline $\mathrm{TL} \times \mathrm{CR}$ & $* *$ & NS & $*$ \\
\hline $\mathrm{CC} \times \mathrm{CR}$ & NS & NS & NS \\
\hline $\mathrm{TL} \times \mathrm{CC} \times \mathrm{SD}$ & NS & NS & NS \\
\hline $\mathrm{TL} \times \mathrm{CR} \times \mathrm{SD}$ & NS & NS & * \\
\hline $\mathrm{CC} \times \mathrm{CR} \times \mathrm{SD}$ & NS & NS & NS \\
\hline $\mathrm{TL} \times \mathrm{CC} \times \mathrm{CR} \times \mathrm{SD}$ & NS & NS & NS \\
\hline
\end{tabular}

\section{Conclusions}

The soil physical properties reported in the current study indicate interactions between tillage systems x cover crop and cover crop x crop rotation (majorly in 2012 and 2013); the effect of the cover crop was more apparent in no-tillage and in rotations than in monoculture at $0-10 \mathrm{~cm}$ depth. After 3 years of study, cover crop improved pore space indices (increased Ds/Do and reduced $\tau$ ) at $0-10 \mathrm{~cm}$ depth. We can therefore conclude that no tillage, cover crop and crop rotation have positive effects on soil pore space indices. Our results can be helpful to the farmers of central Missouri and other regions with similar soil to decide on crop management practices which can enhance agricultural resilience.

Author Contributions: Conceptualization, N.V.N.; Methodology, N.V.N.; Investigation, N.V.N.; Writing—original draft preparation, D.P.; Writing—review and editing, D.P. and N.V.N.; Visualization, D.P. and N.V.N.; Project administration, N.V.N.; Funding acquisition, N.V.N. Both authors have read and agreed to the published version of the manuscript.

Funding: This research is part of a regional collaborative project supported by the USDA-NIFA, Award No. 2011-68002-30190, “Cropping Systems Coordinated Agricultural Project: Climate Change, Mitigation, and Adaptation in Corn-based Cropping Systems." Project Web site: http: / / sustainablecorn.org (accessed on 24 June 2020). 
Institutional Review Board Statement: Not applicable.

Informed Consent Statement: Not applicable.

Data Availability Statement: The data presented in this study are available on request from the corresponding author.

Acknowledgments: For technical support during soil sampling and laboratory analyses, the authors are grateful to Brandon Mebruer and Samuel I. Haruna. We would like to thank two anonymous reviewers and an academic editor for their valuable comments and suggestions, which helped us in improving this paper.

Conflicts of Interest: The authors declare no conflict of interest.

\section{References}

1. Abad, J.R.S.; Khosravi, H.; Alamdarlou, E.H. Assessment the Fffects of Land Use Changes on Soil Physicochemical Properties in Jafarabad of Golestan Province, Iran. Bull. Environ. Pharmacol. Life Sci. 2010, 3, 296-300.

2. Woniala, J.; Nyombi, K. Soil Fertility Management by Smallholder Farmers and the Impact on Soil Chemical Properties in Sironko District, Uganda. Res. J. Agric. For. Sci. 2014, 2, 5-10.

3. Panday, D. Adapting climate change in agriculture: The sustainable way in Nepalese context. Hydro Nepal. J. Water Energy Environ. 2012, 13, 91-94. [CrossRef]

4. Materechera, S.A. Influence of Agricultural Land Use and Management Practices on Selected Soil Properties of a Semi-arid Savanna Environment in South Africa. J. Arid Environ. 2014, 102, 98-103. [CrossRef]

5. Bhatt, R.; Khera, K.L. Effect of Tillage and Mode of Straw Mulch Application on Soil Erosion in the Submontaneous Tract of Punjab, India. Soil Tillage Res. 2006, 88, 107-115. [CrossRef]

6. Mosaddeghi, M.R.; Mahboubi, A.A.; Safadoust, A. Short Term Effects of Tillage and Manure on Some Soil Physical Properties and Maize Root Growth in a Sandy Loam Soil in Western Iran. Soil Tillage Res. 2009, 104, 173-179. [CrossRef]

7. Daniells, I.G. Hard-setting soils: A review. Soil Res. 2012, 50, 349-359. [CrossRef]

8. Rasmussen, K.J. Impact of Plough-less Soil Tillage on Yield and Soil Quality: A Scandinavian Review. Soil Tillage Res. 1999, 53, 3-14. [CrossRef]

9. Mathew, R.P.; Feng, Y.; Githinji, L.; Ankumah, R.; Balkcom, K. Impact of No-tillage and Conventional Tillage on Soil Microbial Communities. Appl. Environ. Soil Sci. 2012, 2012, 548620. [CrossRef]

10. Pikul, J.L.; Schwartz, R.C.; Benjamin, J.G.; Baumhardt, R.L.; Merrill, S. Cropping system influences on soil physical properties in the Great Plains. Renew. Agric. Food Syst. 2006, 21, 15-25. [CrossRef]

11. Keisling, T.C.; Scott, H.D.; Waddle, B.A.; Williams, W.; Frans, R.E. Winter Cover Crops Influence on Cotton Yield and Selected Soil Properties. Commun. Soil Sci. Plant. Anal. 1994, 25, 3087-3100. [CrossRef]

12. Steele, M.K.; Coale, F.J.; Hill, R.L. Winter Annual Cover Crop Impacts on No-till Soil Physical Properties and Organic Matter. Soil Sci. Soc. Am. J. 2012, 76, 2164-2173. [CrossRef]

13. Abdollahi, L.; Munkholm, L.J.; Garbout, A. Tillage System and Cover Crop Effects on Soil Quality: II. Pore Characteristics. Soil Sci. Soc. Am. J. 2013, 78, 271-279. [CrossRef]

14. Sulc, R.M.; Tracy, B.M. Integrated Crop-Livestock Systems in the U.S. Corn Belt. Agron. J. 2007, 99, 335-345. [CrossRef]

15. Clark, A. Managing Cover Crops Profitably, 3rd ed.; DIANE Publishing: Darby, PA, USA, 2008.

16. Haruna, S.I.; Anderson, S.H.; Udawatta, R.P.; Gantzer, C.J.; Phillips, N.C.; Cui, S.; Gao, Y. Improving soil physical properties through the use of cover crops: A review. Agrosyst. Geosci. Environ. 2020, 3, e20105. [CrossRef]

17. Calonego, J.C.; Raphael, J.P.; Rigon, J.P.; de Oliveira Neto, L.; Rosolem, C.A. Soil compaction management and soybean yields with cover crops under no-till and occasional chiseling. Eur. J. Agron. 2017, 85, 31-37. [CrossRef]

18. Stone, L.R.; Schlegel, A.J. Tillage and crop rotation phase effects on soil physical properties in the west-central Great Plains. Agron. J. 2010, 102, 483-491. [CrossRef]

19. Haruna, S.I.; Nkongolo, N.V. Tillage, Cover Crop and Crop Rotation Effects on Selected Soil Chemical Properties. Sustainability 2019, 11, 2770. [CrossRef]

20. Dexter, A.R.; Czyż, E.A.; Niedzwiecki, J.; Maćkowiak, C. Water retention and hydraulic conductivity of a loamy sand soil as influenced by crop rotation and fertilization. Arch. Agron. Soil Sci. 2001, 46, 123-133. [CrossRef]

21. Głąb, T.; Ścigalska, B.; Łabuz, B. Effect of crop rotations with triticale ( $\times$ Triticosecale Wittm.) on soil pore characteristics. Geoderma 2013, 202, 1-7. [CrossRef]

22. Truua, M.; Truua, J.; Ivaskb, M. Soil Microbiological and Biochemical Properties for Assessing the Effect of Agricultural Management Practices in Estonian cultivated soils. Eur. J. Soil Biol. 2008, 44, 231-237. [CrossRef]

23. Allaire, S.E.; Caron, J.; Duchesne, I.; Parent, L.É.; Rioux, J.A. Air-filled porosity, gas relative diffusivity, and tortuosity: Indices of Prunus $\times$ cistena sp. growth in peat substrates. J. Am. Soc. Hortic. Sci. 1996, 121, 236-242. [CrossRef]

24. Logsdon, S.D.; Karlen, D.L. Bulk density as a soil quality indicator during conversion to no-tillage. Soil Tillage Res. 2004, 78 , 143-149. [CrossRef] 
25. Alam, M.; Islam, M.; Salahin, N.; Hasanuzzaman, M. Effect of tillage practices on soil properties and crop productivity in wheat-mungbean-rice cropping system under subtropical climatic conditions. Sci. World J. 2014, 2014, 437283. [CrossRef] [PubMed]

26. Panday, D.; Nkongolo, N.V. Comparison of models for predicting pore space indices and their relationships with $\mathrm{CO}_{2}$ and $\mathrm{N}_{2} \mathrm{O}$ fluxes in a corn-soybean field. Can. J. Soil Sci. 2016, 96, 328-335. [CrossRef]

27. Hudson, T.; Aharonson, O. Diffusion barriers at Mars surface conditions: Salt crusts, particle size mixtures, and dust. J. Geophys. Res. Plantes 2008, 113, E9. [CrossRef]

28. Lee, J.; Hopmans, J.W.; Rolston, D.E.; Baer, S.G.; Six, J. Determining soil carbon stock changes: Simple bulk density corrections fail. Agric. Ecosyst. Environ. 2009, 134, 251-256. [CrossRef]

29. Nkongolo, N.V.; Hatano, R.; Kakembo, V. Diffusivity models and greenhouse gases fluxes from a forest, pasture, grassland and corn field in northern Hokkaido. Pedosphere 2010, 6, 747-760. [CrossRef]

30. Teepe, R.; Brumme, R.; Beese, F.; Ludwig, B. Nitrous oxide emission and methane consumption following compaction of forest soils. Soil Sci. Soc. Am. J. 2004, 68, 605-611. [CrossRef]

31. Nkongolo, N.V.; Kuramochi, K.; Ryusuke, H. Effect of mechanized tillage operations on soil physical properties and greenhouse gases fluxes in two agricultural fields. Res. J. Environ. Sci. 2008, 2, 68-80. [CrossRef]

32. Pellegrini, S.; Vignozzi, N.; Batistoni, E.; Pagliai, M. Macroporosity and saturated hydraulic conductivity of a silty clay soil as affected by different applied pressure, moisture content and land use. In Geophysical Research Abstracts-European Geosciences Union; European Geosciences Union: Munich, Germany, 2006; Volume 8, p. 03001.

33. Girei, A.H.; Nabayi, A.; Amapu, I.Y.; Mudiare, O.J.; Abdulkadir, A. Models for predicting pore space indices of an irrigated lowland rice soil in a Sudan Savanna of Nigeria. J. Res. For. Wildlife Environ. 2020, 12, 183-191.

34. Nkongolo, N.V.; Caron, J.; Gauthier, F.; Yamada, M. Organic wastes for improving soil physical properties and enhancing plant growth in container substrates. J. Crop. Prod. 2001, 3, 97-112. [CrossRef]

35. U.S. Climate Data. Climate Jefferson City-Missouri. 2019. Available online: https://www.usclimatedata.com/climate/jeffersoncity/missouri/united-states/usmo0453 (accessed on 24 June 2019).

36. Kladivko, E.J.; Helmers, M.J.; Abendroth, L.J.; Herzmann, D.; Lal, R.; Castellano, M.J.; Mueller, D.S.; Sawyer, J.S.; Anex, R.P.; Arritt, R.W.; et al. Standardized research protocols enable transdisciplinary research of climate variation impacts in corn production systems. J. Soil Water Conserv. 2014, 69, 532-542. [CrossRef]

37. Marshall, T.J. Permeability and the size distribution of pores. Nature 1957, 180, 664-665. [CrossRef]

38. Buckingham, E. Contributions to Our Knowledge of the Aeration of Soils; Bureau of Soils, U.S. Department of Agriculture: Washington, DC, USA, 1954; Volume 25.

39. Sallam, A.; Jury, W.A.; Letey, J. Measurement of gas diffusion coefficient under relatively low air-filled porosity. Soil Sci. Soc. Am. J. 1984, 48, 3-6. [CrossRef]

40. Moldrup, P.; Kruse, C.W.; Rolston, D.E.; Yamaguchi, T. Modeling diffusion and reaction in soils: III. Predicting gas diffusivity from the Campbell soil-water retention model. Soil Sci. 1996, 161, 366-375. [CrossRef]

41. Jin, Y.; Jury, W.A. Characterizing the dependence of gas diffusion coefficient on soil properties. Soil Sci. Soc. Am. J. 1996, 60, 66-71. [CrossRef]

42. Bauer, A.; Black, A.L. Soil Carbon, Nitrogen, and Bulk Density Comparisons in Two Cropland Tillage Systems after 25 Years and in Virgin Grassland. Soil Sci. Soc. Am. J. 1981, 45, 1166-1170. [CrossRef]

43. NRCS. Soil Quality Kit, Guides for Educators. USDA. n.d. Available online: https://www.nrcs.usda.gov/Internet/FSE_ DOCUMENTS/nrcs142p2_053260.pdf (accessed on 21 June 2019).

44. Lampurlanés, J.; Cantero-Martínez, C. Soil bulk density and penetration resistance under different tillage and crop management systems and their relationship with barley root growth. Agron. J. 2003, 95, 526-536. [CrossRef]

45. Nascente, A.S.; Li, Y.; Crusciol, C.A. Soil aggregation, organic carbon concentration, and soil bulk density as affected by cover crop species in a no-tillage system. Rev. Bras. Ciênc. Solo. 2015, 39, 871-879. [CrossRef]

46. Shah, A.N.; Tanveer, M.; Shahzad, B.; Yang, G.; Fahad, S.; Ali, S.; Bukhari, M.A.; Tung, S.A.; Hafeez, A.; Souliyanonh, B. Soil compaction effects on soil health and crop productivity: An overview. Environ. Sci. Poll. Res. 2017, 24, 10056-10067. [CrossRef]

47. Calonego, J.C.; Rosolem, C.A. Soil aggregate stability after management with crop rotation and chiseling. Rev. Bras. Ciênc. Solo. 2008, 32, 1399-1407. [CrossRef]

48. Unger, P.W. Overwinter changes in physical properties of no-tillage soil. Soil Sci. Soc. Am. J. 1991, 55, 778-782. [CrossRef]

49. Gregorich, E.G.; Lapen, D.R.; Ma, B.L.; McLaughlin, N.B.; VandenBygaart, A.J. Soil and crop response to varying levels of compaction, nitrogen fertilization, and clay content. Soil Sci. Soc. Am. J. 2011, 75, 1483-1492. [CrossRef]

50. Wagger, M.G.; Denton, H.P. Influence of Cover Crop and Wheel Traffic on Soil Physical Properties in Continuous No-Till Corn. Soil Sci. Soc. Am. J. 1989, 53, 1206-1210. [CrossRef]

51. Haruna, S.I.; Nkongolo, N.V. Effects of tillage, rotation and cover crop on the physical properties of a silt-loam soil. Int. Agrophys. 2015, 29, 137-145. [CrossRef]

52. Chalise, K.S.; Singh, S.; Wegner, B.R.; Kumar, S.; Pérez-Gutiérrez, J.D.; Osborne, S.L.; Nleya, T.; Guzman, J.; Rohila, J.S. Cover crops and returning residue impact on soil organic carbon, bulk density, penetration resistance, water retention, infiltration, and soybean yield. Agron. J. 2019, 111, 99-108. [CrossRef] 
53. Ferreira, E.A.; Resck, D.V.; Gomes, A.C.; Ramos, M.L. Carbon dynamics of microbial biomass at five times of year in different Cerrado soil management systems. Braz. J. Soil Sci. 2007, 31, 1625-1635.

54. Blanco-Canqui, H.; Holman, J.D.; Schlegel, A.J.; Tatarko, J.; Shaver, T.M. Replacing fallow with cover crops in a semiarid soil: Effects on soil properties. Soil Sci. Soc. Am. J. 2013, 77, 1026-1034. [CrossRef]

55. Liu, A.; Ma, B.L.; Bomke, A.A. Effects of cover crops on soil aggregate stability, total organic carbon, and polysaccharides. Soil Sci. Soc. Am. J. 2005, 69, 2041-2048. [CrossRef]

56. De Moraes, M.T.; Bengough, A.G.; Debiasi, H.; Franchini, J.C.; Levien, R.; Schnepf, A.; Leitner, D. Mechanistic framework to link root growth models with weather and soil physical properties, including example applications to soybean growth in Brazil. Plant Soil 2018, 428, 67-92. [CrossRef]

57. Fujikawa, T.; Miyazaki, T. Effects of bulk density and soil type on the gas diffusion coefficient in repacked and undisturbed soils. Soil Sci. 2005, 170, 892-901. [CrossRef]

58. Joyce, B.A.; Wallender, W.W.; Mitchell, J.P.; Huyck, L.M.; Temple, S.R.; Brostrom, P.N.; Hsiao, T.C. Infiltration and soil water storage under winter cover cropping in California's Sacramento Valley. Trans. ASAE 2002, 45, 315-326. [CrossRef]

59. Nielsen, D.C.; Vigil, M.F.; Lyon, D.J.; Higgins, R.K.; Hergert, G.W.; Holman, J.D. Cover crops can affect subsequent wheat yield in the central great plains. Crops Soils 2016, 49, 51-53. [CrossRef]

60. Basche, A.; Kaspar, T.C.; Archontoulis, S.V.; Jaynes, D.B.; Sauer, T.J.; Parkin, T.B.; Miguez, F.E. Soil water improvements with the long-term use of a winter rye cover crop. Agric. Water Manag. 2016, 172, 40-50. [CrossRef]

61. Haruna, S.I. Influence of winter wheat on soil thermal properties of a Paleudalf. Int. Agrophys. 2019, 33, 389-395. [CrossRef]

62. Lipiec, J.; Hatano, R. Quantification of Compaction Effects on Soil Physical Properties and Crop Growth. Geoderma 2003, 116, 107-136. [CrossRef]

63. Moldrup, P.; Olesen, T.; Yoshikawa, S.; Komatsu, T.; Rolston, D.E. Three-porosity model for predicting the gas diffusion coefficient in undisturbed soil. Soil Sci. Soc. Am. J. 2004, 68, 750-759. [CrossRef]

64. Ball, B.C.; O'Sullivan, M.F.; Hunter, R. Gas diffusion, fluid flow and derived pore continuity indices in relation to vehicle traffic and tillage. J. Soil Sci. 1988, 39, 327-339. [CrossRef]

65. Chou, H.; Wu, L.; Zeng, L.; Chang, A. Evaluation of solute diffusion tortuosity factor models for variously saturated soils. Water Resour. Res. 2012, 48, W10539. [CrossRef]

66. Galdos, M.V.; Pires, L.F.; Cooper, H.V.; Calonego, J.C.; Rosolem, C.A.; Mooney, S.J. Assessing the long-term effects of zero-tillage on the macroporosity of Brazilian soils using X-ray Computed Tomography. Geoderma 2019, 337, 1126-1135. [CrossRef] [PubMed]

67. Vizioli, B.; Cavalieri-Polizeli, K.M.V.; Tormena, C.A.; Barth, G. Effects of long-term tillage systems on soil physical quality and crop yield in a Brazilian Ferralsol. Soil Tillage Res. 2021, 209, 104935. [CrossRef]

68. Reeleder, R.D.; Miller, J.J.; Coelho, B.B.; Roy, R.C. Impacts of tillage, cover crop, and nitrogen on populations of earthworms, microarthropods, and soil fungi in a cultivated fragile soil. Appl. Soil Ecol. 2006, 33, 243-257. [CrossRef]

69. Nkongolo, N.V.; Caron, J. Pore space organization and plant response in peat substrates: I. Prunus x cistena and Spiraea japonica. Sci. Res. Essays 2006, 1, 077-086. 